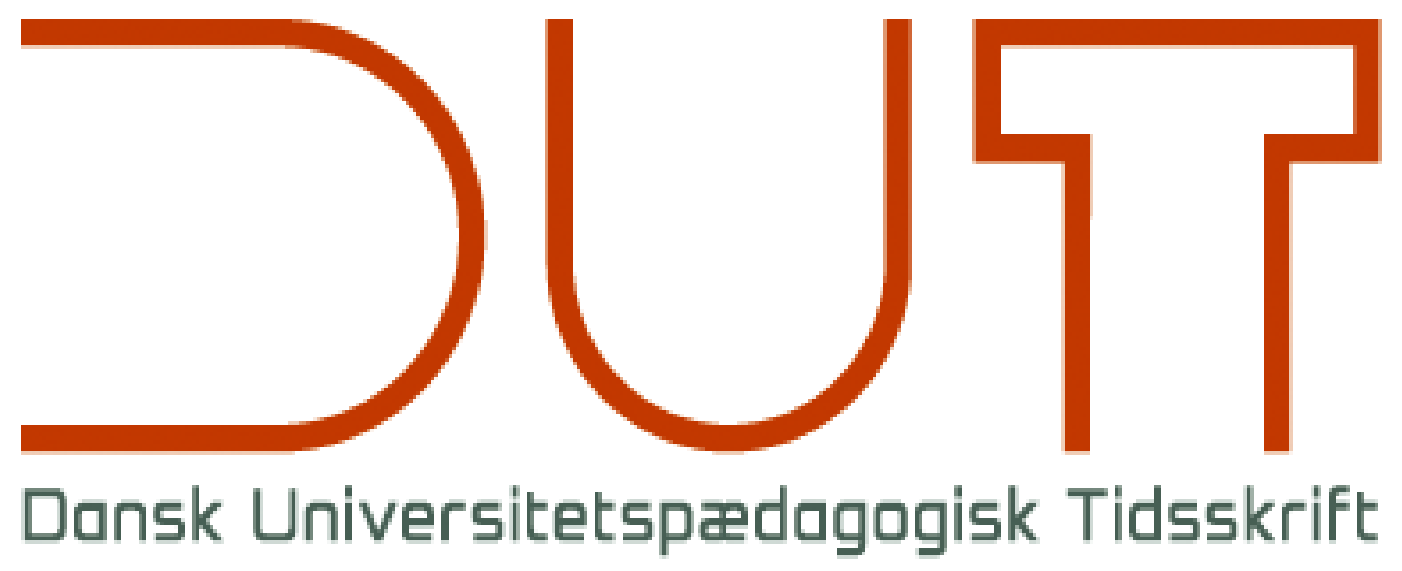

Tema

Ledelse, udvikling og overlevelse på universitetet

Årgang 12 nr. 22 / 2017

Titel

Udvikling af studerendes akademiske skrivekompetencer - en model for en indsats på fakultetsniveau

Forfatter

Sidetal

Tine Wirenfeldt Jensen, Gina Bay og Per Andersen

$88-98$

Udgivet af

Dansk Universitetspædagogisk Netværk, DUN

URL

> http://dun-net.dk/

Betingelser for brug af denne artikel

Denne artikel er omfattet af ophavsretsloven, og der må citeres fra den. Følgende betingelser skal dog være opfyldt:

- Citatet skal være i overensstemmelse med "god skik“

- Der må kun citeres „i det omfang, som betinges af formålet“

- Ophavsmanden til teksten skal krediteres, og kilden skal angives ift. ovenstående bibliografiske oplysninger. 


\section{Udvikling af studerendes akademiske skrivekompetencer - en model for en indsats på fakultetsniveau}

Tine Wirenfeldt Jensen, ph.d., Syddansk Universitet, METoDo

Gina Bay, MBU, bibliotekar, AU Library, Aarhus Universitet

Per Andersen, prodekan, Aarhus BSS, Aarhus Universitet

\section{Faglig artikel (bedømt af redaktionen)}

I artiklen præsenteres en model for, hvordan den faglige ledelse på enkeltuddannelser og den faglige ledelse på tværs af flere uddannelser (her konkret et helt fakultet) kan igangsætte arbejdet med udviklingen af de studerendes akademiske skrivekompetencer på en måde, der er forankret i de enkelte faglige miljøer og samtidig muliggør opsamling af erfaringer og behov på tværs af fag. Modellen er udviklet og afprøvet i forbindelse med et projekt afviklet i efteråret 2015 i et samarbejde mellem samtlige syv institutter på Aarhus BSS ved Aarhus Universitet. Særligt fremhæves tre af modellens styrker: 1. modellen faciliterer, at flere centrale faglige aktører involveres i arbejdet med at understøtte de studerendes skrivekompetencer, 2. modellen giver indsigt i de studerendes aktuelle udfordringer og behov på tværs af et fakultet (her i form af 354 skriftlige evalueringer) og 3. modellen har vist potentiale til at motivere fagene til at fortsætte arbejdet med at understøtte de studerendes skrivekompetencer på egen hånd og tilføre nødvendig viden til dette fortsatte arbejde.

\section{Baggrund: Skrivevanskeligheder og fremdriftsreform}

I de senere år har en række faktorer været med til at skabe et fornyet fokus på, hvordan man kan understøtte de studerendes skrivekompetencer. Det drejer sig især om tre faktorer: øget studenterdiversitet, øget fokus på studerendes og nyuddannedes skriftlige kompetencer samt reformen af SU-systemet og rammerne for studiegennemførelse (den såkaldte fremdriftsreform).

Den øgede studenterdiversitet har medført et endnu stærkere behov for at eksplicitere den tavse viden, der er forbundet dels med forventninger til udformning og indhold af akademiske opgaver, dels hvordan en faglig skriveproces kan forløbe. Den $\emptyset$ gede studenterdiversitet ses i forhold til danske studerende, der kommer med forskellige baggrunde og i meget varierende grad kan trække på familie og netværk i forbindelse med deres studier. Samtidig medfører den øgede internationalisering af uddannelserne, at studerende fra andre uddannelsestraditioner skal afkode de implicitte forventninger til den akademiske genre på en dansk uddannelsesinstitution (udgivelser som The Good Paper (Rienecker \& Jørgensen, 2013) og Aarhus Universitets 
webressource The Study Metro er fx rettet mod denne målgruppe). Samtidig er en konsekvens af den øgede internationalisering, at mange danske studerende forventes at skrive opgaver på engelsk, et krav der ikke altid ledsages af uddannelse heri (Cozart et al., 2015).

I pressen har der været sat fokus på universitetsstuderendes manglende skrivefærdigheder fra både underviseres og censorers side under titler som 'Studerende er for dårlige til at skrive' (Meyer, 2015), 'Studerende må altså lære at skrive' (Drothner, 2015) og 'Hjælpeløse studerende i videnskabsteoretisk kaos' (Dahl, 2013).

Artiklerne omtaler forskellige tiltag på universiteterne, ligesom det diskuteres, hvorvidt gymnasieskolen gør nok for at gøre de studerende klar til at skrive på universitetet. I forbindelse med det her beskrevne udviklingsprojekt pegede flere fag på forhånd på, at også aftagerpaneler indimellem udpeger nyuddannede kandidaters skrivefærdigheder som et område, der kan forbedres. Flere studieledere og undervisere nævnte en tendens til et såkaldt 'sms-sprog' i enkelte studerendes opgaver, hvilket kan skyldes, at nogle studerende har vanskeligt ved at afkode, hvad der sprogligt forventes i skriftlige opgaver og derfor har svært ved at tilpasse deres skriftsprog til situationen.

Fremdriftsreformen har betydet, at rammerne for de studerendes arbejde med skriftlige opgaver er ændret. Tidligere kunne studerende, der havde svært ved at skrive opgaver (både studerende med faglige udfordringer og fagligt stærke studerende, der oplever udfordringer med skriveprocessen og egne høje krav), håndtere dette ved at sænke studieintensiteten. Fx ved at udsætte en opgave til en sommerferie eller et semester med færre skriftlige opgaver. Denne strategi er ikke længere mulig i samme grad. For specialestuderende gælder det, at alle er berørt af reformen. Specialestart er nu i mindre grad til forhandling, og den reelle tid, der er til rådighed for at skrive speciale, er afkortet. Hvor meget det drejer sig om er forskelligt på tværs af uddannelser og universiteter, men der er for en stor dels vedkommende tale om blot fire-seks måneder til at skrive speciale. Om det er muligt at ændre på specialets rammer uden at ændre på læringsudbyttet, og hvilke konsekvenser det i så fald måtte have, er et spørgsmål, der ikke har haft så fremtrædende rolle i diskussionen om at ændre på eksamensformen, som man kunne ønske (Jensen, 2016). Men en klar konsekvens af fremdriftsreformen er, at det nu bliver endnu vigtigere, at studerende har de nødvendige proceskompetencer til at styre deres skriftlige opgaver og få dem afleveret til tiden.

På baggrund af blandt andet disse udfordringer blev der i efteråret 2015 sat fokus på at styrke de studerendes skrivekompetencer på Aarhus BSS, hvor samtlige syv institutter, med deres respektive uddannelsesporteføljer, valgte at involvere sig i projektet. De involverede uddannelser var Statskundskab, Økonomi, Erhvervsøkonomi, Jura, HA(jur.), Psykologi samt Erhvervssprog og Erhvervskommunikation. 


\section{Afsæt og mål i arbejdet med at udvikle skrivekompetencer}

Arbejdet med at styrke universitetsstuderendes akademiske skrivekompetencer kan forstås og designes på forskellige måder. Særligt diskussioner, som er meget tæt koblet til amerikanske uddannelsesforhold og traditioner, fylder meget i litteraturen, $\mathrm{fx}$ litteraturen om writing centers (Murphy \& Law, 2013; Gillespie, 2001). Der må derfor tages en række forbehold i forhold til at overføre pointer til en dansk kontekst. Skulle man dog udpege to overordnede pointer, der meningsfuldt kan overføres til danske forhold, kunne man fremhæve 1. at alle undervisere skal have fokus på at opbygge skrivekompetencer som en integreret del af at lære i den specifikke fagdisciplin og 2. at der indtænkes en overordnet progression i udviklingen af skrivekompetencer i forhold til hele uddannelsen (se fx Wingate, 2006; Hagström, 2005; Lea \& Street, 1998).

For de fleste universitets- og skrivepædagoger vil disse pointer være indlysende rigtige. Men samtidig er det også pointer, der er meget omfattende at implementere og fx kan kræve ændringer af studieordninger, fagbeskrivelser og undervisningsformer samt efteruddannelse af undervisere. I realiteten vil det sjældent være muligt at anskue de to nævnte pointer som et afsæt for undervisningsudvikling på området - de må snarere opfattes som et langsigtet mål.

På danske universiteter har initiativer rettet mod at styrke studerendes akademiske skrivekompetencer da også overvejende taget form af enkeltstående tiltag med varierende tilknytning til de faglige miljøer. I en dansk sammenhæng har arbejdet med at understøtte studerendes skrivekompetencer været placeret i et forhandlingsfelt, hvor det kontinuerligt er blevet diskuteret, dels om det overhovedet er universitetets opgave at beskæftige sig med dette emne, og om man blot bør kunne forudsætte, at de studerende kan skrive, dels hvem der overhovedet kan og må gå ind i dette arbejde (fx interne og eksterne undervisere, instruktorer, mentorer, studievejledninger, universitetspædagogiske enheder, skrivecentre eller støtte- og rådgivningscentre.) Men med den øgede studenterdiversitet og internationalisering samt indførelsen af fremdriftsreformen er der skabt en ny situation, hvor det ikke længere meningsfuldt kan forudsættes, at alle studerende på egen hånd kan tilegne sig de akademiske skrivekompetencer, der er nødvendige for at gennemføre en universitetsuddannelse. Der er derfor brug for nye initiativer på området - initiativer, der medtænker forskningslitteraturens pointer og omfattende anbefalinger, men samtidig også er konkrete og gennemførlige i praksis.

I det følgende beskrives en model for, hvordan den faglige ledelse på enkeltuddannelser og den faglige ledelse på tværs af flere uddannelser (som fx et fakultet) kan igangsætte arbejdet med udviklingen af de studerendes akademiske skrivekompetencer på en måde, der er er forankret i de enkelte faglige miljøer og samtidig muliggør opsamling af erfaringer og behov på tværs af fag og uddannelser. Modellen er udviklet på baggrund af de erfaringer, der blev gjort, da prodekanen for uddannelse på Aarhus 
BSS ved Aarhus Universitet og studielederne for fakultetets fuldtidsuddannelser i efteråret 2015 sammen med en skrivekonsulent med speciale i akademisk skrivning gennemførte et fælles, men fagligt differentieret forløb på tværs af samtlige syv institutter på Aarhus BSS. Den efterfølgende evaluering gjorde det muligt at samle op på erfaringerne på tværs af flere uddannelser og dermed synliggøre, hvad der fungerede godt, og hvad der fungerede mindre godt - den faglige diversitet gav således grobund for at udvikle en model, der både tager fagspecifikke hensyn og kan adressere gennemgående behov og problematikker.

\section{En model i fire trin}

Formålet med projektet var i udgangspunktet at udvikle de studerendes forståelse for den akademiske genres krav og deres faglige skrive- og feedbackkompetencer. Til det formål udviklede skrivekonsulenten i tæt samarbejde med fagene en model i fire trin: 1. dialog med fagdisciplinerne, 2. udvikling og afholdelse af workshops om akademisk skrivning, 3. udarbejdelse af digital ressourceside og 4. videndeling.

\section{Trin 1: Dialog med fagdisciplinerne}

For at sikre en tæt dialog med fagdisciplinerne tog skrivekonsulenten som det første skridt kontakt til alle fakultetets studieledere. Modellen krævede forankring på studielederniveau, dels for at arbejdet kunne have den nødvendige legitimitet, dels for at muliggøre dialog med studielederen og udpegede/interesserede undervisere, instruktorer og studievejledere. Studieledere har adgang til og indsigt i de samlede lokale undervisningserfaringer, hvilket sikrede, at centrale problemer er blevet taget op. Studielederen har også kunnet pege på, hvordan indsatsen lokalt skulle udformes, fx hvilke fag eller studietrin, der måtte have et særligt behov. På seks ud af syv institutter var der et tæt samarbejde med studielederen. På det fag, hvor studieledere uddelegerede opgaven til en underviser med særlig interesse for området, blev det nødvendigt med ekstra forventningsafstemmende møder med kritiske undervisere, hvilket var med til at skabe et refleksionsrum for undervisernes forskellige forventninger til de studerendes opgaver.

Et gennemgående tema i mødet med fagene var, hvordan den konkrete faglige disciplin formede kravene til opgaver. For akademisk skrivning er altid skrivning i en specifik faglig kontekst, og selv om fagene udpegede mange fælles problemer i de studerendes opgaver, så er der også forhold, der er meget tæt knyttet til de forskellige fags indhold, traditioner og metoder (se også fx Blåsjø, 2004). Det er helt afgørende, at der lægges et arbejde $\mathrm{i}$ at kortlægge de enkeltes fags særlige udfordringer sammen med studieleder og undervisere, gerne med inddragelse af studerende (i denne sammenhæng fx instruktorer og studievejledere). Denne dialog har ikke kun fungeret som afsæt for projektet, men udgør et vigtigt resultat i sig selv. 
Fagene har i kraft af deres forskellighed også meget forskellige ressourcer til rådighed i forhold til at indgå i et udviklingsprojekt om akademisk skrivning. Nogle fag har i kraft af deres genstandsfelt mindre plads i studieprogrammerne til at opbygge skriftlige kompetencer end andre, fordi andre centrale færdigheder skal opbygges. Andre fag har stærke faglige konventioner for udformningen af skriftligt arbejde uden nødvendigvis at have en høj grad af eksplicitering og begrebsliggørelse af disse traditioner og krav i forhold til opgavegenren. Endelig har kommunikations- og sprogfag skriftlighed som fagligt genstandsfelt, og studieledere og undervisere på den type fag forsker selv i emnet, hvilket skaber nogle særlige betingelser ift. at indgå i et samarbejde med dem.

En diskussion i forskningslitteraturen, der har vist sig produktiv at inddrage i samtaler med de faglige miljøer, var, hvorvidt opbygningen af akademiske skrivefærdigheder bør konceptualiseres inden for rammen study skills eller academic literacy (Lea \& Street, 1998; Wingate, 2006). I det første perspektiv forstås akademisk skrivning som en løsrevet teknisk færdighed, og i det sidste perspektiv forstås akademisk skrivning som dybt integreret med det faglige genstandsfelt, historie og tænkemåde. Denne diskussion har udspillet sig på forskellig vis, men den grundlæggende pointe har været taget op alle steder og et fokus på literacy frem for skills vagte genklang i større eller mindre grad alle steder.

\section{Trin 2: Udvikling og afholdelse af workshops om akademisk skrivning}

På baggrund af dialog mellem skrivekonsulenten, studieledere og undervisere blev der udviklet workshops om akademisk skrivning målrettet det enkelte fags behov. I alt afholdte skrivekonsulenten 48 workshops, og undervisere og instruktorer fra de involverede uddannelser deltog i undervisningen i varierende grad. På Jura blev der udviklet et forløb bestående af tre workshops rettet mod specialestuderende i tæt samarbejde med en underviser på Jura, der også fungerede som medunderviser under hele forløbet. På andre uddannelser har undervisere og instruktorer deltaget i undervisningstilrettelæggelsen og/eller overværet undervisningen i nogen grad eller slet ikke.

De afholdte workshops var primært målrettet speciale- og BA-projektskrivere, men der blev også afholdt workshops rettet mod instruktorer, studievejledere, internationale studerende samt 1. og 3. semesterstuderende. Størstedelen af workshopperne varede tre timer, enkelte to timer. Der blev afholdt workshops både på dansk og engelsk. En stor del af workshopperne blev afholdt som et forløb bestående af tre sammenhængende workshops med fokus på hhv. akademisk argumentation, akademiske skrive- og arbejdsprocesser og peer feedback samt brug af vejledning.

I forlængelse af diskussioner med de faglige miljøer blev det et mål for indsatsen, at de studerende ikke blot opfattede workshops om akademisk skrivning som snæver eksamenstræning, men blev i stand til at opfatte akademisk skrivning som et foran- 
derligt felt. Et felt, der formes af fagets kontinuerlige forhandlinger af normer og kriterier, herunder forholdet mellem konkurrerende videnskabsteoretiske positioner (Lillis \& Turner, 2001). Akademiske skriveworkshops har potentialet til at åbne et rum for denne type refleksion.

\section{Trin 3: Udarbejdelse af digital ressourceside}

Som en metode til at skabe blivende værdi for de involverede fag udformede skrivekonsulenten ressourcesider med relevant materiale om akademisk skrivning til uddannelsernes hjemmesider (studieportalerne). Den litteratur, der var blevet inddraget i de afholdte workshops, blev dermed i kommenteret form gjort tilgængelig for fremtidige studerende. En ambition var at inddrage de lokale fagbibliotekarer i dette arbejde. Bibliotekerne spiller en vigtig rolle i forhold til at understøtte de studerendes opgaveskrivning, og bibliotekerne udformer selv hjemmesider målrettet studerende om litteratursøgning og referencehåndtering, samt hvordan litteratursøgning konstruktivt kan hjælpe til at konkretisere, udvikle og afgrænse problemstillinger i den tidlige fase af opgaveskrivningen.

Pga. tidspres blev denne ambition kun delvist indfriet: På et fag blev en hel workshop tilrettelagt og afholdt i samarbejde med en fagbibliotekar, på et andet fag deltog en fagbibliotekar i undervisningen med et kort oplæg, og på et par andre fag foregik en mailkorrespondance efterfølgende vedrørende udvælgelse af titler til den digitale ressourceside. På tre fag var der ingen kontakt med biblioteket. På dette punkt kunne projektet have været styrket ved en mere systematisk tilgang til at involvere bibliotekerne i udviklingsprojektet.

\section{Trin 4: Videndeling}

Gennem skriftlige evalueringer fra 354 studerende, fordelt på Jura, Statskundskab, Psykologi, Erhvervskommunikation, Økonomi og Erhvervsøkonomi, blev det muligt for skrivekonsulenten at indhente viden om de studerendes erfaringer med og perspektiver på akademisk skrivning. Evalueringsskemaet blev udleveret på papir og udfyldt i sidste del af undervisningen. Skemaet inviterede til både besvarelse af en række spørgsmål og at komme med kommentarer. Efterfølgende blev de studerendes evalueringer af skrivekonsulenten samlet og systematiseret i en digital version, der sammen med papirevalueringerne blev sendt til de enkelte fag.

På baggrund af disse evalueringer udarbejdede skrivekonsulenten notater til de enkelte uddannelser, hvor særlige indsatsområder og pointer blev udpeget, og mulige løsninger blev skitseret. Disse notater er på forskellig uformel og formel vis delt internt i organisationen - nogle har fx sendt dem videre til undervisere involveret i projektet, andre steder er de diskuteret i studienævnet.

Særligt de studerendes skriftlige evalueringer har givet en omfattende opdateret viden om moderne universitetsstuderendes behov i forhold til akademisk skrivning. Det 
vil føre for vidt i denne sammenhæng at behandle evalueringerne fyldestgørende, men disse tre punkter bør fremhæves:

For det forste er det tydeligt i evalueringerne, at mange studerendes indgang til undervisning i akademisk skrivning er en forventning om at få serveret en række helt håndfaste anvisninger på, hvordan man skal skrive en universitetsopgave. At få åbnet et refleksionsrum, for at de normer og krav, der eksisterer i forhold til akademisk skrivning, er et resultat af forhandlinger og er dybt forbundne med videnskabsteoretiske diskussioner, bliver dermed et læringsmål i sig selv (se også trin 2). Af kommentarerne i evalueringerne fremgår det, at dette mål i hvert fald for nogle studerendes vedkommende blev nået.

For det andet har undervisningen i, hvordan de studerende kan arbejde med struktureret peer feedback i forbindelse med opgaveskrivning, afstedkommet en række kommentarer fra de studerende, hvor de reflekterer over tidligere erfaringer med peer feedback. Dette citat er udvalgt, fordi det som eksempel indfanger en gennemgående pointe:

"I fagene [X] og [X], hvor der skal gives feedback på skriveøvelser til holdtimerne, er jeg $100 \%$ sikker på, at det ville have hjulpet mit hold, hvis vi var blevet introduceret til, hvordan man faktisk giver feedback! Det var der ingen af os, som vidste, derfor fungerede det overhovedet ikke, hvilket var ærgerligt. Jeg kan derfor kun anbefale, at nye studerende bliver introduceret til feedback, da det er et rigtigt godt redskab."

I de senere år har flere af de enkelte uddannelser og Center for Undervisning og Læring gjort en indsats for at få indarbejdet mere peer feedback og klæde underviserne på til dette. Evalueringerne peger på, at det er værd at undersøge, om også de studerende har brug for at blive bedre klædt på til at indgå i dette arbejde.

For det tredje dukker et nyt tema op i både evalueringerne og i undervisningen, et fænomen der kan benævnes 'plagiatangst'. De studerende efterspørger gode råd til, hvordan de kan være helt sikre på ikke at blive anklaget for at have plagieret. Flere fortæller om, hvor nervøse de er for at blive anklaget for at have plagieret, selv om de har gjort alt, hvad de kan for at undgå dette. Det er studerende, der er godt bekendt med citatteknik m.m., men som frygter at plagiatkontrolprogrammer alligevel ville kunne identificere steder i deres opgave, der ville blive opfattet som plagiat. Forskellige plagiatsager har fyldt en del i medierne, og de studerende er bevidste om, at selv eksperter kan have forskellige opfattelser af, hvad der bør klassificeres som plagiat. Samtidig igangsættes der kampagner mod snyd målrettet studerende (se fx http://studerende.au.dk/proever/eksamenssnyd, hvor det understreges, at også utilsigtet plagiat straffes og kan indebære risiko for bortvisning). Det skaber tilsammen et landskab, hvor plagiat ikke er omfattet af entydige og let afkodelige regler, og hvor plagiat 
kan 'afsløres' af computerprogrammer, de studerende ofte ikke kan gennemskue hvordan fungerer. Endeligt er konsekvenserne af en plagiatsag potentielt meget voldsomme for den enkelte studerende. For nogle studerende - og langt flere, end forfatterne havde forudset - skaber denne situation decideret plagiatangst, helt på linje med begreberne eksamensangst og præstationsangst.

Plagiatangst kan lede til en række uheldige strategier, der kolliderer med de krav, der stilles til studerende i selvstændige universitetsopgaver. Som en studerende sagde i forbindelse med en workshop: "Jeg har fundet en løsning - nu siger jeg bare ikke noget selv". Den studerende undgik helt konkret at skrive noget som helst, uden at der var 'en kilde på'. Det er svært at se, hvordan denne strategi skal kunne resultere i en større, selvstændig opgave, hvor der netop ligger en genreforventning om, at den studerende skal kunne arbejde med kilder med det formål at kunne fremsætte et selvstændigt argument. Plagiatangst og de medfølgende uheldige strategier kan ikke fjernes ved at ved at udstyre de studerende med et antal simple regler, for diskussionen om, hvad der udgør plagiat i de enkelte fagtraditioner, er ikke enkel. Der ligger et arbejde i forhold til denne problematik - et arbejde, der må tage afsæt i at anerkende problemets kompleksitet, og at det ikke kan adresseres løsrevet fra det faglige fællesskab.

Ovenstående tre pointer er vigtige at medtænke i det fortsatte arbejde med at understøtte udviklingen af de studerendes skrivekompetencer.

\section{Modellen som afsæt for uddannelsesudvikling}

Efter projektets afslutning har de involverede uddannelser meldt tilbage på udviklingsprojektet i form af skriftlige tilbagemeldinger til fakultetsledelsesniveau. Af tilbagemeldingerne fremgår det, at de involverede uddannelser har vurderet projektet og dets udbytte positivt. Modellen har den fordel, at den kan gennemføres med et fornuftigt udbytte uden i udgangspunktet at kræve omfattende ændringer af fx studieordninger, og uden at hver enkelt underviser bliver pålagt at skulle løfte endnu en opgave i sin egen individuelle undervisning. På danske universiteter tager initiativer rettet mod at styrke studerendes akademiske skrivekompetencer overvejende form af enkeltstående tiltag med varierende tilknytning til de faglige miljøer, og dermed muliggøres erfaringsopsamling på tværs af fag relativt sjældent. Ved at arbejde på fakultetsniveau kan man sætte ellers individuelle og spredte tiltag på området ind i en overordnet ramme, der muliggør, at erfaringer kan opsamles og deles.

Men modellens største styrke har vist sig at være dens potentiale til at virke som en katalysator for fortsat udviklingsarbejde, samtidig med at den bidrager med viden, der er en forudsætning for et sådant udviklingsarbejde. På et helt konkret niveau kan dette potentiale iagttages $\mathrm{fx}$ ved at:

- en uddannelse er i gang med at undersøge, om undervisning i akademisk skrivning kan tænkes sammen med et eksisterende fag 
- en uddannelse har taget initiativ til et projekt, der samler undervisere og bibliotekarer for at sikre progression i det skriftlige arbejde på BA-uddannelsen

- tre uddannelser har i foråret 2016 afholdt forløbet for egne midler og har ønsket løbende at opsamle og diskutere studenterevalueringerne

At afholde en række workshops målrettet studerende et enkelt efterårssemester og udarbejde ressourcesider kan virke som en forfejlet strategi, hvis målet er at skabe varige forandringer. Men de nævnte tiltag tjener til at skabe en dialog på tværs af og mellem alle de aktører, der er nævnt. Det er denne dialog og den viden om de studerendes behov og forventninger, som workshopperne har kastet af sig, der har potentiale til at skabe fortsat udvikling. At over 400 studerende derudover har deltaget $\mathrm{i}$ undervisning om akademisk skrivning er, sammenlignet hermed, blot et biprodukt. For at undgå at et projekt som dette foregår løsrevet fra de enkelte uddannelser, er det helt afgørende, at udviklingsprojektet forankres hos studielederne, og at undervisningen udformes i tæt dialog med både dem, fagets undervisere samt instruktorer/studievejledere. Samtidig er det en forudsætning, at der som udgangspunkt er en vis interesse fra uddannelsernes side i forhold til at styrke de studerendes skrivekompetencer, samt at de nødvendige faglige kompetencer og midler er til stede.

\section{Konklusion}

De studerende står i dag overfor en række nye udfordringer i forhold til at opbygge skrivekompetencer: 1) de kommer i langt højere grad end tidligere med mange forskellige baggrunde og forudsætninger, 2) de forventes i større eller mindre omfang at kunne skrive akademiske tekster på engelsk, 3) de skriftgenrer, de i deres dagligdag udtrykker sig igennem, er meget forskellige fra den akademiske genre, 4) fremdriftsreformen har øget presset i forhold til at kunne skrive opgaver inden for en stram tidsramme og 5) det store fokus på plagiat kan lede til angst og uheldige strategier i forhold til opgaveskrivning.

Disse udfordringer betyder, at det er vigtigere end nogensinde at understøtte de studerende i at kunne opbygge skrivekompetencer på universitetet. Der findes ingen nemme løsninger på området, og sporadiske og enkeltstående tiltag rækker ikke. Det er en forudsætning, at både studieledere, undervisere, studerende (studievejleder/instruktorer) og bibliotekerne involveres i arbejdet og sammen opsamler og udveksler erfaringer. Men hverken de studerende eller uddannelserne kan på den anden side være tjent med, at der intet sker, mens man afventer den perfekte løsning på et komplekst problem. Den her beskrevne model i fire trin er mulig at gennemføre, og modellen har formået at igangsætte dialog mellem de relevante aktører, har muliggjort indsamling af viden om de studerendes behov i forhold til akademisk skrivning og har motiveret flere af de involverede uddannelser til på forskellig vis selv at fortsætte udviklingsarbejdet. Den udgør kort sagt et sted at starte. 
Tine Wirenfeldt Jensen er ph.d. i Learning \& Education med en afhandling om det danske universitetsspeciale. Hun er ekstern adjunktvejleder på SDU og samarbejder gennem sit firma METoDo med en række danske uddannelsesinstitutioner om undervisningsudvikling. Tine har arbejdet med akademisk skrivning på universitetsniveau i 15 år og har udviklet ressourcer som Studiemetroen og Tekstfeedbackspillet.

Gina Bay, bibliotekar, MBU, AU Library, Bartholins Allé, Aarhus Universitet. Gina vejleder og underviser i struktureret og systematisk litteratursøgning og assisterer med opbygning af konsistente søgestrategier til literature reviews. Hun er medforfatter til Scribo, der er et redskab til at udvikle problemformulering og litteratursøgning.

Per Andersen, prodekan for uddannelse, Aarhus BSS, Aarhus Universitet. Han er tidligere studieleder på Juridisk Institut på Aarhus Universitet og underviser og forsker i retshistorie, juridisk metode og andre almene retsvidenskabelige fagområder.

\section{Litteratur}

Blåsjö, M. 2004. Studentersskrivande i två kunskapsbyggande miljöer. Institutionen för nordiska språk, Stockholms universitet. Ph.d.-afhandling.

Cozart, SM, Jensen, TW, Wichmann-Hansen, G, Kupatadze, K \& Chien-Hsiung Chiu , S. 2015, 'Negotiating Multiple Identities in Second- or Foreign-Language Writing in Higher Education'. i JL Moore \& C Anson (red), Critical Transitions: Writing and the Question of Transfer. WAC Clearinghouse Publishing and Parlor Press, USA.

Dahl, H, 25.06.2013. "Hjælpeløse studerende i videnskabsteoretisk kaos". Kommunikationsforum, www.kommunikationsforum.dk/artikler/hjaelpeloesestuderende-i-videnskabsteoretisk-kaos

Drottner, K, 3.02. 2015. "Studerende må altså lære at skrive". Politiken, http://politiken.dk/debat/ECE2532074/studerende-maa-altsaa-laere-at-skrive/

Hagström, E. 2005. Meningar om uppsatsskrivande i högskolan. Ph.d.-afhandling. Örebro University, Department of Education.

Lea, M. R. \& B. V. Street. 1998. "Student writing in higher education: An academic literacies approach." Studies in higher education 23.2.

Meyer, I, 26.02. 2015."Studerende er for dårlige til at skrive", Berlingske, http://www.b.dk/nationalt/studerende-er-for-daarlige-til-at-skrive

Murphy, C., \&J. Law. 2013. Landmark essays on writing centers. Vol. 9. Routledge. Jensen, T.W. 2016. Bjerget og sumpen - en undersøgelse af det danske universitetsspeciales betydninger med afsæt i humaniora. Ph.d.-afhandling, Aarhus Universitet.

Rienecker, L. \& P.S. Jørgensen. 2013. The Good Paper. Samfundslitteratur.

The Study Metro. http://studiemetro.au.dk/en/. Aarhus Universitet.

Wingate, U. 2006. "Doing away with 'study skills'." Teaching in Higher Education. 11.4: 457-469. 
Gillespie, P., et al., eds. 2001. Writing center research: Extending the conversation. Routledge.

Lillis, T. \&J. Turner. 2001. "Student writing in higher education: contemporary confusion, traditional concerns." Teaching in Higher Education. 6.1: 57-68. 